\title{
知識成長過程を指向した設計意図知識管理システ 么の構築
}

\section{Development of a System for Capturing Design Rationale with Inte- gration of Dynamic Knowledge Management}

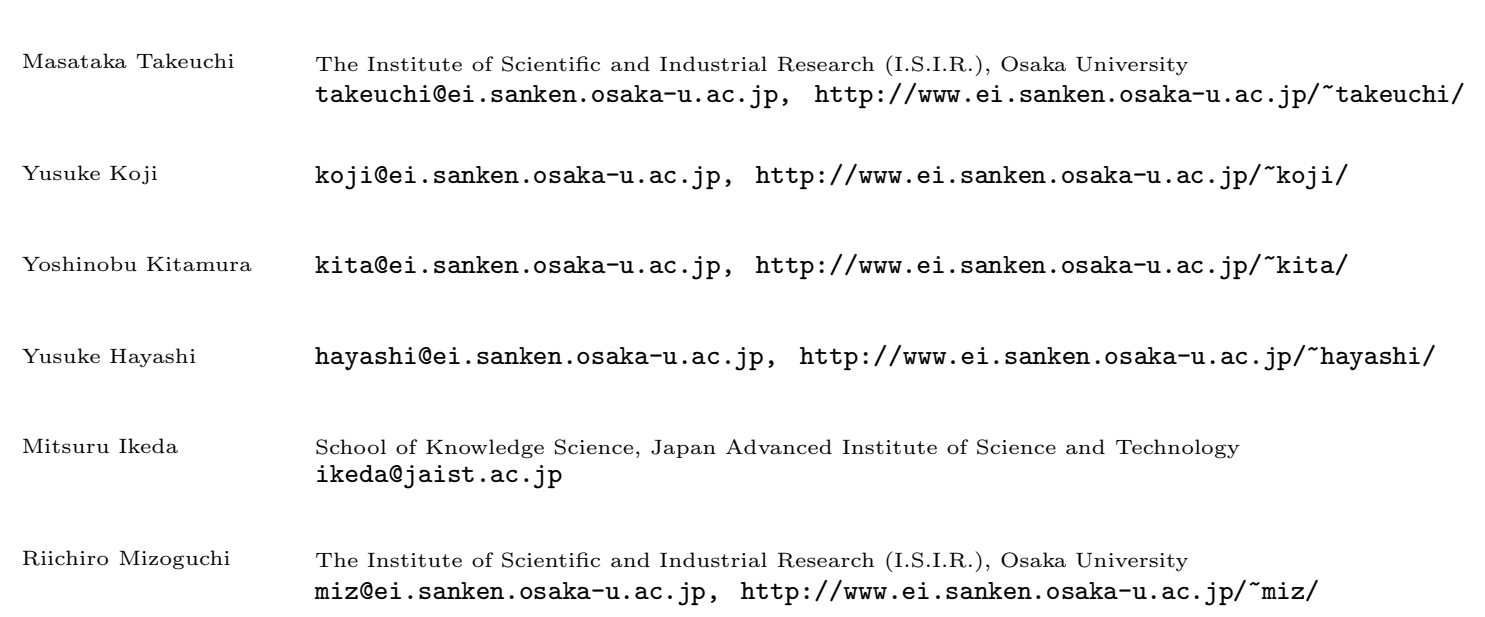

keywords: design process, functional knowledge, ontology, knowledge management tool

\section{Summary}

It has been recognized that design rationale is necessary for understanding and designing artifacts. In order to capture it, we focus on functional knowledge as design rationale and have developed a functional knowledge modeling tool, named SOFAST, which has been deployed in a few companies. In this paper, we aim to capture the processes related to functional knowledge which are not dealt with by the current SOFAST. We discuss a systematic description and an automatic capture system of two typical processes: modification process of functional decomposition trees in the context of designer's daily jobs, and systematization processes in which functional knowledge grows. For the implementation of the system, we extended SOFAST using an ontology-based Knowledge Management framework. Through demonstration and trial use of the system, SOFAST's users positively evaluated the system's effectiveness and expectable usefulness for their daily work.

\section{1.は じめ に}

\section{人工物の設計の根拠や設計の背後にある知識は総称し} て設計意図と呼ばれ [Lee 97], 弚の利用価値の高さは設 計工学, 機能表現, 価値工学などの分野における多くの 研究が示唆しているように広く認識されている.設計意 図は人工物の理解において欠かすことのできない存在で あるため, 多くの管理・記述支援システムが構築されて きた .しかし , システムによる設計意図の把握は難しく， 日常業務への浸透は進んでいない [Regli 00]. 弚の理由 の 1 つとして, 設計意图は属人性が強く暗黙的になりが ちなため汎用性・一貫性を保って記述することが難しい ことがある .

システムによる設計意図の把握は, 設計段階によって
概念設計段階のものと詳細設計段階のもので仕組みが異 なるだけでなく，同じ設計段階でも設計対象の機能と構 造のどちらの知識に着目するかでも異なる . 筆者らは概 念設計段階における機能的知識の汎用性・一貫性を保っ た記述に向けて，機能に関するオントロジーと乥れに基 づく機能的知識の体系化枠組み [來村 02a] を構築してき た、機能的知識は人工物の果たす役割と目的を表し $[\mathrm{Pahl}$ 88, 冨山 90], 設計意図の中でも人間の認識により近いレ ベルにあり恣意性が強い .

本研究はこの機能的知識に注目した設計意図の把握 ・ 管理を大きな目標としている.この枠組みの構筑を通し て機能的知識の管理・記述支援システムに関する知見を 蓄積してきており，光の 1 つとしてシステムに求められ る機能について整理したものを以下にあげる．また，文 
献は乥れに注目している研究を表す。

(1) 最終設計案について機能の達成関係を明確な形て記 述し，再利用性を向上させる枠組み [ 來村 02a, Chandrasekaran 93] .

（2）最終設計案だけでなく，不採用設計案や見送った 設計案 (不採用理由等を含む) の蓄積 [Koji 05] .

(3) 設計案の作成・変更・修正過程のキャプチャ(設計 案の検討・解析・実験過程や, 改良が必要になった 理由を含む) [野間口 05, 間瀬 02] .

(4) 再発・繰り返しの防止に貢献する設計上の問題 解決過程の蓄積 (不具合と光の対処の専門知識を含 む) [Kunz 70, McCall 91] .

（5）設計案に記述しきれない情報を補うための設計者 の関わり方の提示 [Klein 93] .

（6）参考にされてきた知識を発見するための参照履歴 の明示化 [武田 94] .

(7) 知識の体系化を促し，弚の一般化・体系化過程を 明示化する枠組み .

（8）設計意图を捉えるという単ーゴール設定ではない， 日常業務と連携のとれた統合的な知識管理の枠組み [Davenport 98]

設計意図の捉え方には設計対象物としての捉え方 (機 能・構造等) と設計過程としての捉え方がある .上記に おいて (1)，(2) は前者を，(3)〜 (7) は後者を支援する機 能である . 過程を捉える観点には (3) : 設計案 , (4) : 問 題 (issue) ・案 (position) だけでなく，(5)：人，(6) : 知 識，(7)：個別知識・汎用知識がある . (3)，(4) の観点で 捉えた過程を設計過程とすることは多いが，本研究では (3) を基本に (5)〜 (8) の観点も加えた機能的知識に関わ る過程を対象にする .

筆者らはこれまで, 前述の (1)，(2) に関して機能的知 識の体系化枠組みを構築してきた [Kitamura 04] . 詳細 は 2 章で説明するが, この枠組みは産業界において実用 化されて大きな効果を上げ, 兴の過程で開発されたのが 機能的知識記述ツール SOFAST である . 人工物の「機 能構造」の記述を支援する高い能力を持つ. (3)〜 (7) に ついては，作成番号の記録，不具合・副作用の記述，参 考ドキュメントの埋め込みといった形で不十分ながら実 現している.SOFAST は単体て機能的知識を管理してお り (8) 統合的な環境への拡張も課題とされていた .

本研究では, 機能的知識に関する統合的な記述・把握・ 管理支援システムの構築を目指している . 本稿は谷の中 でも機能的知識の成長過程に着目したものである . 知識 の成長過程に関してはナレッジマネジメントなどでの研 究が進んでおり，本研究では光の知見を活かして設計過 程記述枠組みを構筑する．本研究で開発するシステムは この枠組みが基盤であり，従来のSOFAST で実現され た機能的知識の記述支援と統合して設計意図に関する知 識管理環境を提供するとともに，機能的知識の成長過程 を自動的にキャプチャすることで改良設計や技術の進歩
などの把握を支援する .

本稿ではまず，本研究の基盤として筆者らがこれまで に関わってきた機能的知識の体系化枠組みについて概要 を説明する (2 章) . 次に機能的知識に関わる過程の記述 枠組みについて述べ (3 章), 弚の枠組みに基づくシステ ムの機能設計 (4 章) および光の実装・評価について述べ る (5 章). 最後に, 関連研究との比較を通して本システ ムについてまとめる $(6$ 章 $)$.

\section{2. 機能的知識を捉える 基盤}

一般的に，ある機能はさらに詳細なグレインサイズで 捉えた部分機能の組み合わせによって達成される，機能 を異なるグレインサイズで捉えた結果の機能達成階層は 概念設計における機能分解 [Pahl 88] の結果を示してお り，乥れをモデル化したものが機能分解木である.

一般に，機能分解は設計者に依存する部分が大きく，一 貫性・汎用性を保ったまま記述するのは難しい．本研究 で基礎としている機能的知識の記述枠組みでは，機能分 解木の一貫性と再利用性を向上させる制約として，機能 オントロジーと方式知識を導入している．

機能オントロジーは，機能分解木で用いられる各機能 を定義したオントロジーである.このオントロジーでは 機能の定義を「要求された目標の下で振る舞いを解釈し たもの」とし，100あまりの機能概念を定義し，階層的 に体系化している [來村 02a] .

方式知識は，各機能がどのようにして達成されるかと いう機能分解の理由を表す知識であり, 機能の達成（分 解) 関係を兴の原理に基づいて分類・体系化している.方 式知識は機能を参照しているため, 機能に対して明確な 定義を与える機能オントロジーは，機能分解木だけでな く方式知識の記述基盤でもある.この方式知識に基づき 機能に関する what と how を切り分けることで, 機能分 解木の適切な記述や方式知識の体系化が進み，これらを 再利用することが容易になる [來村 $02 b]$.

図 1 に, 上記の枠組みに基づいて記述したワイヤソー 装置の機能分解木を示す．ワイヤソー装置は半導体生産 プロセスにおけるインゴットの切断装置である . 楕円形 ノードが機能を表わし, 各機能を四角ノードで関係付け たものが方式知識を表わしている .

機能オントロジーでは「分割する」「減らす」などの機 能が定義されており，図 1 上部の「インゴットを分割す る」「切り代部の結合力を減らす」などは, 光の具体化に なっている。

方式知識の $1 つ 「$ 除去方式」は『「分割する」を「(結 合力を) 減らす」と「離す」によって達成する』と記述さ れる.図 1 上部では，この方式が『「インゴットを分割す る」を「切り代部の結合力を減らす」と「切り代 (くず) を離す」で達成する』として具体化されている。

一般に，ある機能を達成する方式知識は複数存在する． 


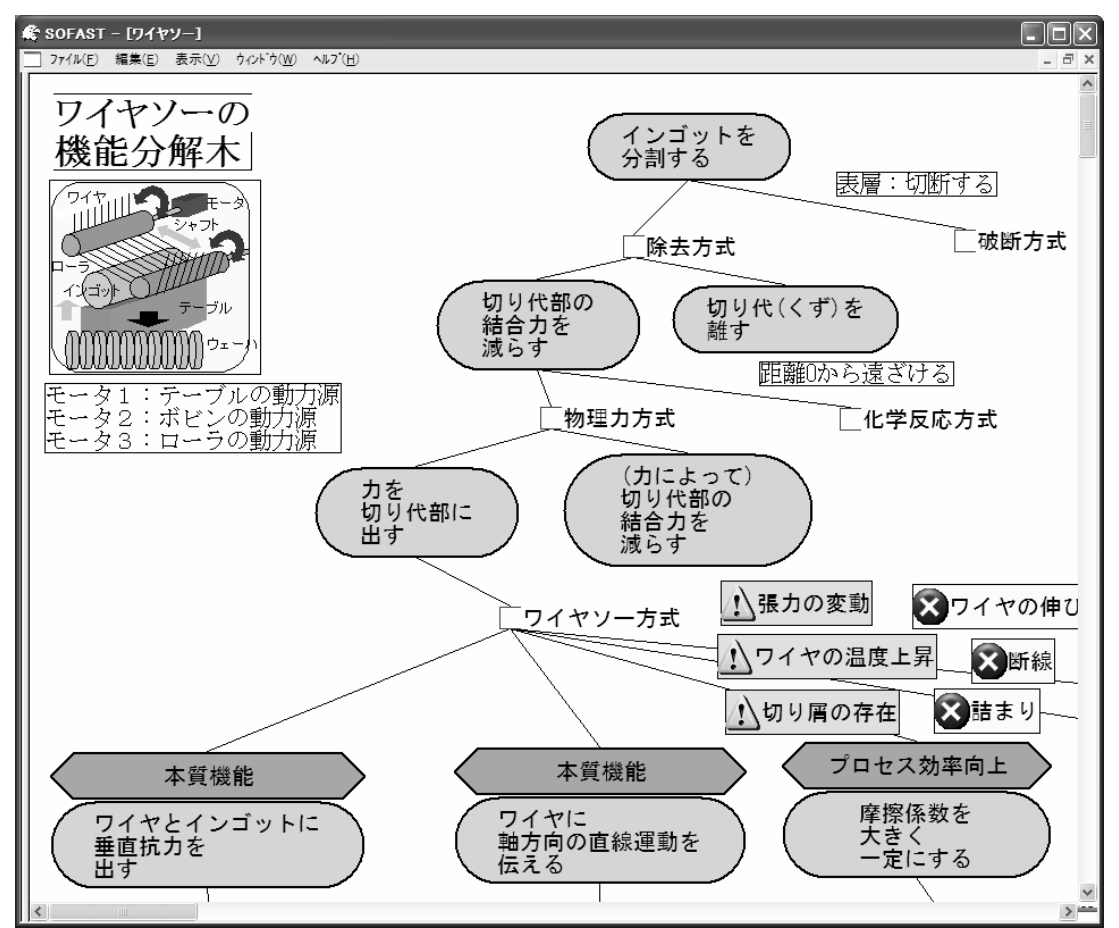

図 1 機能的知識記述ツール SOFAST の画面例 (ワイヤソーの機能分解木の一部を表示)

設計対象で用いる方式の採用・不採用について, 設計対 象固有の不具合・副作用の記述 (図 1 の×印，! 印)によ り，設計根拠の一部を残すことができる .

本枠組みの一部は民間企業において生産に関わる装置 の機能的知識管理に実運用されており，例えばデザイン レビューのやり直し回数の削減, 特許申請のクレームの 強化, 従来手法て解決できなかった品質問題の解決など 大きな成果をあげている [溝口 02, 布瀬 03] . 機能的知 識記述ツール SOFAST は本枠組みに基づいて開発され， ユーザーズグループも組織されている .

\section{3. 機能的知識の修正・体系化過程の記述枠組 みとその記述}

2 章で述べた機能分解木には 2 つの過程か関係してい る.設計対象の挙動 (機能発揮過程) と, 設計者の行為過 程 (設計案の修正・洗練過程や, 知識の再利用性・汎用性 を高める過程) である . 前者は機能分解木内に記述され るが, 後者は機能分解木自身の変化過程として捉えられ る . 両者の過程は光の対象が異なるために明確に区別さ れる. 機能分解木を用いた概念設計では, 機能分解木自 身の変化過程か機能的知識に関する設計過程といえる .

本研究ではこれらの過程を統合的に扱う枠組みの構築 を目指しているが，機能発揮過程に関する議論は既にな されているので [來村 $02 \mathrm{~b}]$, 本研究では後者の機能的知 識に関わる設計過程を捉える枠組みに焦点を絞る．以下 に，4章で述べるキャプチャ機能が，日常業務における 設計案の修正過程・方式知識の体系化過程を自動的に取 り込む際に前提としているモデルについて述べる．

\section{$3 \cdot 1$ 機能的知識の修正・体系化過程の記述枠組み}

機能的知識には機能構造 (設計結果, 設計案) と方式知

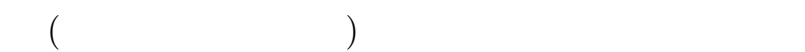
にした過程を考えると，機能構造を対象にした過程は，日 常業務の設計結果が日々明確になる過程であり設計案の 修正過程といえる．また方式知識自身を対象とした過程 は, 設計で使われる知識か設計案から切り離されて知識 の汎用性の高まる過程であり知識の体系化過程といえる .

設計案の修正過程および方式知識の体系化過程に，本 研究ではナレッジマネジメント [Davenport 98, 野中 96] の観点からの意義を位置付ける．この観点では知識の状 態変化でも過程が進む . 例えば，「知識を共有する」過程 は機能構造の变化だけでなく, 知られていない状態から 知られている状態への变化も含む .このような变化の把 握のために理論に基づいて状態を新たに設ける .

ナレッジマネジメントの基礎理論として世界的に広く 知られている理論に，野中らによる「組織的知識創造理 論」がある .この理論は企業でのインタビューを通じて

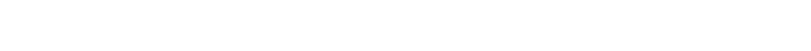
知識には暗黙的な知識と明示的な知識が存在することが 主張されている。

本研究では, 暗黙的知識・明示的知識を設計者と設計 者間の観点から考え，以下の状態を設けた .

・設計者個人において

○内面状態 : 言葉にできない暗黙的な状態

○表出状態 : 言葉にできる明示的な状態

・設計者間において ○個人状態: 他者から認知できない暗黙的な状態 ○共感状態 : 他者から認知できる明示的な状態だが， 
表 1 設計過程を構成する概念 (代表的なものを抜粋)

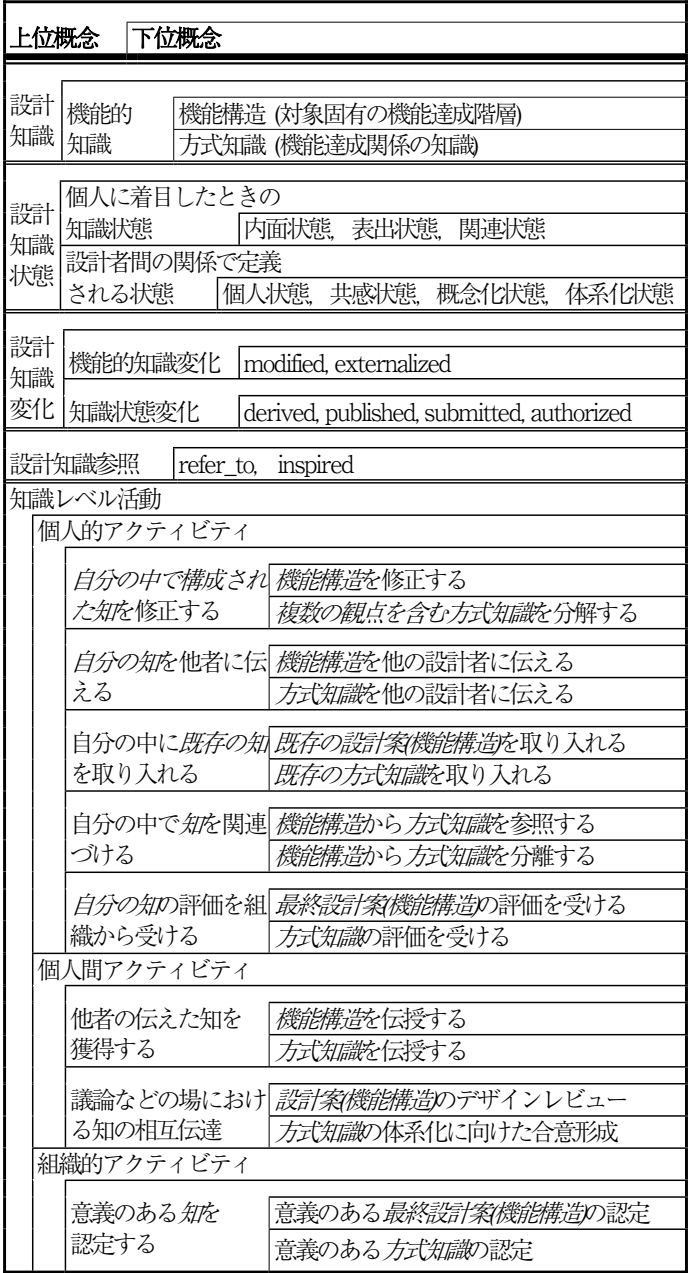

その共有が暗黙的な状態*1

○概念化状態 : 設計者間で共有できる明示的な状態 $* 2$

上記に加えて，設計者個人でも設計者間でも，明示化 された知識は個別ではなく結びついた状態*3が大事であ り [XTM 01, OWL, 溝口 99], 本研究では,

・設計者個人において

。関連状態：個人における他の知識との関連が明示 的な状態

・設計者間において

○体系化状態 : 設計者間で共有した知識の関連が明 示的な状態

を弚れ光れに設けている。

上記の状態に関して，ある状態から次の状態に移行す る状態遷移は，何らかの設計活動か理由となって引きお こされる．例えば，機能構造の個人状態から共感状態へ

*1 ここでの暗黙的とは, 相手に対して内容は伝わるけれども合 意が得られるかどうかは分からないという点で, 暗黙的である

$* 2$ 明示の度合いが考えられ，合意などによって共通の認識とし て明示される状態から, 抽象化や汎用化によって概念的に明示 される状態までを含む

*3 結びついた状態にも度合いが考えられ，個別知識が自由にリ ンクされている状態から，汎用的な知識へと昇華させる体系化 までを含む
の変化には, 設計者による設計案の公開や伝達といった 設計活動がある. 設計案の過程の根拠を表す活動として， 「設計案 (機能構造) を修正する」「機能構造から方式知識 を分離する」といった SOFAST において頻繁にみられる 活動を同定してまとめたものから代表的なものを表 1 に 抜粋した . 光のいくつかの活動について説明する、機能 構造から方式知識を分離する (以下, 分離する)」は，機 能構造から具体的な機能分解のやり方を抜き出して, 方 式知識として切り離す活動を指している．また，「複数の 観点を含む方式知識を分解する (以下, 分解する)」は， 具体的な方式の一般化手法の 1 つとして，一段階の機能 分解に省略がないように複数の方式知識に分割する活動 を指している「意義のある最終設計案 (機能構造) の認 定」「意義のある方式知識の認定」は, 設計者の間で今後 も共有していくべき知識であるかどうかを認定する活動 を指している.本研究では，このような認定を行う主体 として，中間管理職やプロジェクトマネージャなどの設 計活動全体の管理者を想定している．これらの「分離す る」「分解する」「認定する」に対応する具体的な行為に ついては 4.2 節で説明する .

本研究の目的は機能的知識の修正・体系化過程を捉え ることであり，光の過程を記述するための概念について 基盤とする理論とともに本章で議論した . 表 1 に示した 概念で設計に関するあらゆる過程を記述することは意図 していないため，不十分な記述になる過程は存在すると 考えられる.しかし, 各概念は組織論・経学理論などの 結果を踏まえてまとめたものであり，理論によって一般 性・実効性はサポートされる .

\section{$3 \cdot 2$ 機能的知識の修正・体系化過程の記述}

SOFAST て記述される機能分解木には機能発揮過程と 機能分解木自身の変化過程が存在することは述べた . こ の両者はどちらも機能分解木か関わっている過程だが, 異 なる種類の過程であるために明確に区別されるものであ る.このため機能分解木内に記述される機能発揮過程と 混乱することなく，機能分解木光のものの時間的変化を 捉えることができる．本研究ではこの過程を日常業務の 過程との密接な連携を保った形でモデル化し，1 章で述 べた目的の 1 つである (8)「日常業務と連携した知識管 理」を達成する。

\section{$\S 1$ 設計案の修正過程のモデル}

人工物に関する設計案は大なり小なり日々改訂されて いる. 弚の過程は日常業務の忙しさで失われがちだが, 乥 の一部を明示化したのが図 2 である .

図 2 では, 白色ノードが SOFAST で記述された機能 構造を表し，黑色ノードが方式知識を表す . 3.1 節て説明 したように , 同じ内容の機能構造・方式知識であっても 知識管理から見た知識の状態は異なり，ノードの形状で それれぞれの状態を表す. 図 2 は設計者の関わりを中心に した図示のため 4 つの状態で記述している . 知識間の関 
[1]

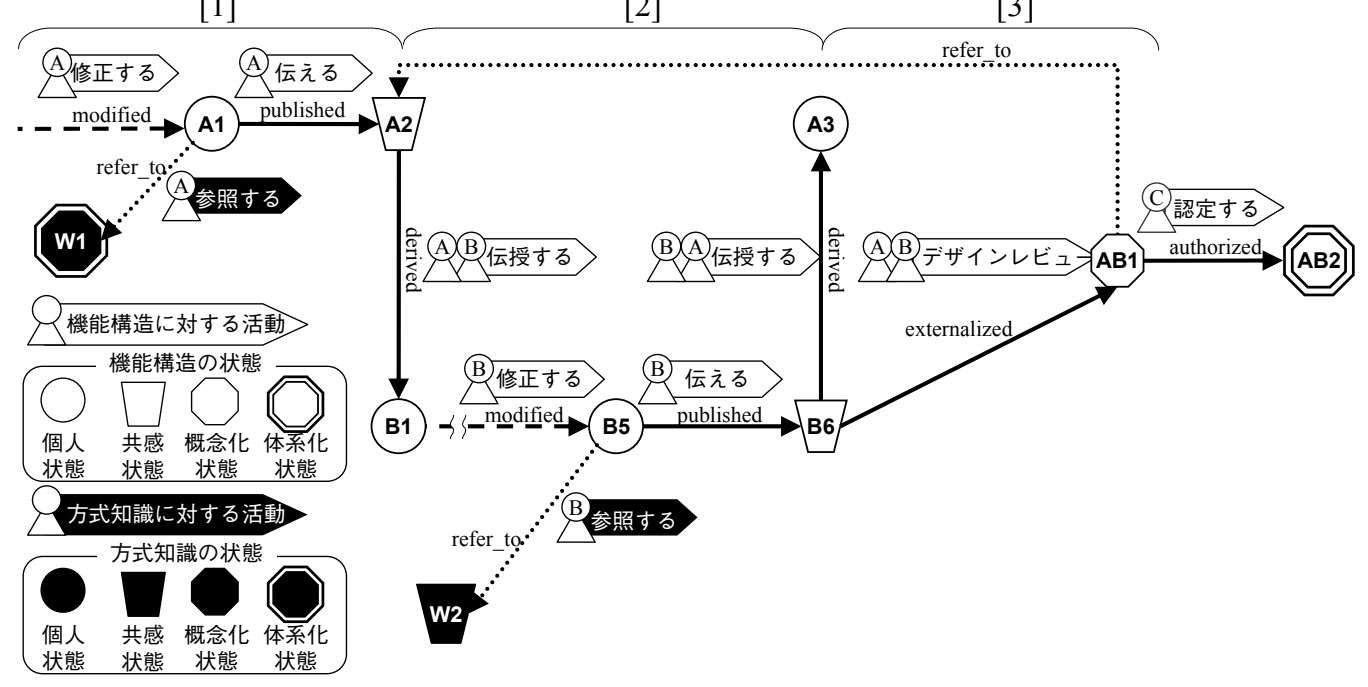

図 2 設計案の修正過程のモデル

係を矢印で表し，同一内容で状態の異なる知識間を実線， 内容の異なる同一状態の知識間を破線, 内容・状態の異 なる知識間を点線で表す。

図 2 を説明上 3 つの部分にわけている .

［1］A 氏が方式知識 W1 を参照しながら設計案 $\mathrm{A} 1$ を 修正し，A 氏の伝える行為により B氏か認知できる 状態の設計案 A2 となった。設計案の伝授は, A 氏 が伝えるだけでなく，B氏が A 氏の設計案を獲得し たときに起こる．B氏の獲得した設計案 B1 は B 氏 か獲得したばかりのものであるのて個人状態となる．

［2］B氏は受けとつた設計案 B1 の修正を繰り返しな がら，あるとき別の方式知識 W2 を参照して修正し た。B氏の伝える行為によって，修正した設計案 B5 は $\mathrm{A}$ 氏の認知できる共感状態の設計案 $\mathrm{B} 6$ になる .

［3］A氏と B氏は互いの設計案をレビューすることに よって合意案 $\mathrm{AB} 1$ を形成した .この案は $\mathrm{A}$ 氏と $\mathrm{B}$

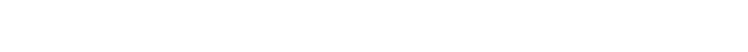
者間で明示的になった設計案となる．このような状 態を本研究では概念化状態と呼んでいる.この設計 案 $\mathrm{AB} 1$ か認定を受ければ体系化状態の設計案 $\mathrm{AB} 2$ となる .

設計案の修正過程を捉えることは, 機能構造をよく知っ ている人の探索や，機能構造の生成のきっかけか誰によ るものであったかなどを知ることができるだけでなく，忘 れさられがちな日常業務の過程を見える形に蓄積し，設 計過程の見直しに貢献する .この例では, 2 つの方式知 識についての検討過程が明示されることで, 誰がどの設 計案にどの方式知識を採用して, 弚の結果どの機能構造 が生成されたのかといった設計過程を蓄積できる．

$\S 2$ 方式知識の体系化過程のモデル

機能的知識の一貫性を保って再利用を促すために，前 述した機能構造の生成・修正とは独立して方式知識を体 系化することは重要である . 方式知識の体系化過程の一 部をモデル化したグラフが図 3 である .
［1］C氏は，提出された設計案 $\mathrm{A} 10$ を参照し，設計 案で用いられている方式知識の中から有用な方式知 識 $\mathrm{C} 4$ を分離した . 分離された直後の方式知識は組 織内でまだ共有されていない個人状態といえる

[ 2] C 氏は, 分離した方式知識 $\mathrm{C} 4$ を再利用しやすく するため，いくつかの方式知識 $(\mathrm{C} 5, \mathrm{C} 6)$ に分解し た . 分解された方式知識はより明確になった概念化 状態といえる。

［3] C 氏は，明確になった方式知識 $\mathrm{C} 6$ を既存の方式 知識体系と関連づけたうえで認定する.認定を受け ることで体系化状態の方式知識 $\mathrm{C} 7$ になる .この方 式知識か溉存の体系にない新しい方式であるときは 方式知識層が充実する .

[ 4]もし既存の体系に同樣の方式知識 C3 があれば， 参照関係が形成されて方式知識の体系化が進む．

方式知識の体系化過程を捉えることで，方式知識がど う用いられたか，どの知識から方式知識が抽出されたの かといった過程の蓄積や提供が可能になる.

\section{4. 機能的知識の修正- 体系化過程キャプチャ 機能}

本研究では, 3 章で説明した機能的知識の修正・体系化 過程のモデルを, SOFAST に関連する日常業務の履歷か ら構成するシステムを開発した . 本システムでは, 日常 的な SOFAST の使用を通して時系列情報をトラッキン グした後，日常業務における機能的知識の成長を適切に キャプチャする .このキャプチャ機能は以下の Tracking 空間から Capture 空間への写像である .

Tracking 空間 日常業務行為が記録される空間.

Capture 空間 機能的知識の修正過程・体系化過程が モデル化される空間

Tracking 空間は SOFAST に関連した日常業務行為が 記録される空間である . 全ての日常業務行為についての 
[1]
[2]

A10

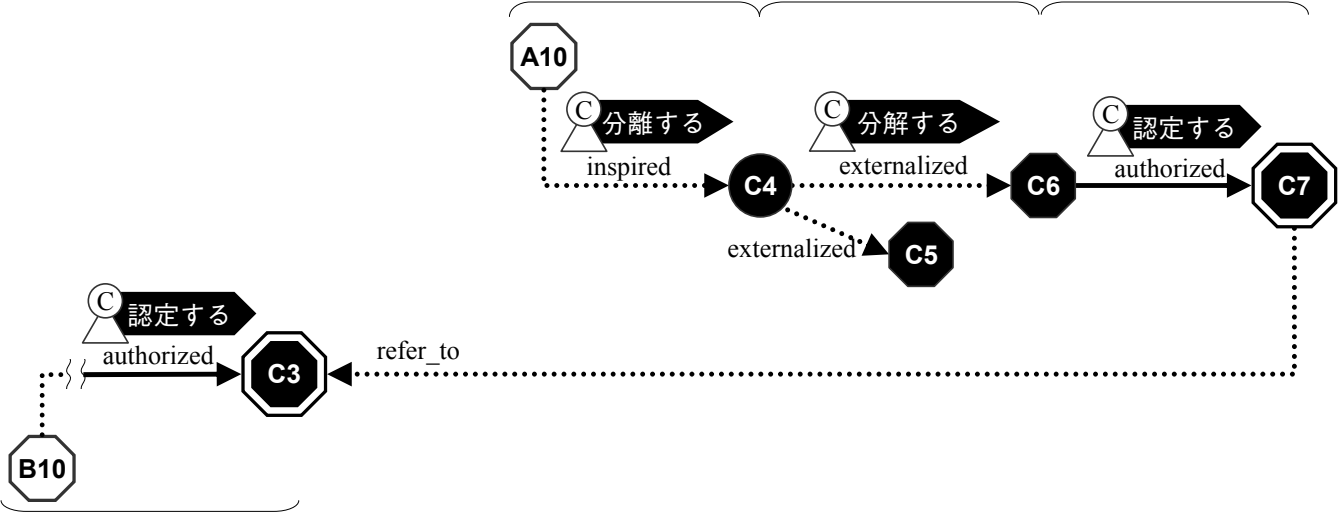

[4]

図 3 方式知識の体系化過程のモデル

完全なトラッキングは極めて困難である . 本研究ではシ ステムで観測可能な日常業務行為としてファイル操作を 想定した . 特に，従来のSOFAST で作成したファイルと その操作を対象にしており，機能構造の記述されたファ イルを機能分解木ファイル, 方式知識の記述されたファ イルを方式ファイルと呼んでいる .これらのファイルは 機能構造や方式知識を特定の形式で表現したものであつ て知識谷のものではない．しかし，知識に極めて近い存 在であるため , これらのファイルの変化をトラッキング することで, 知識の成長過程を推測するのに必要な基礎 情報は集められると考えられる．当然ながらファイル操 作以外にも過程に関する有意義な情報は存在すると考え られるが, 機能構造や方式知識に関する過程を適切に反 映してシステムによるトラッキングも容易なものとして， 上述のファイルと关の操作のトラッキングが十分だと考 えた .このようなファイル操作をトラッキングしようと した場合，設計者による機能分解木のファイルの作成・編 集作業が前提となるが，これらの作業は 2 章でも述べた ように多くのメリットが報告されている．設計者にとつ て設計活動に貢献する作業であってトラッキングのため の負荷にはならないと考える. Tracking 空間に記録さ れる主な要素を抜粋して表 2 に示す. Tracking 空間の構 成は SOFAST のユーザの負担にならないように配慮し， トラッキングのためだけの操作といった新たな負荷の増 加は極力抑える．このことは実用的に極めて重要である．

Capture 空間は機能的知識に関わる過程を人間の認識 に近いレベルで構成した空間である. 3 章で説明した機 能構造の修正過程・方式知識の体系化過程はこの空間で 記述され，弚の構成要素は表 1 に示した概念体系である. この Capture 空間は計算機が Tracking 空間を解釈する ことで構成される．乥のため，解採して意義のある情報 かどうかで取捨選択されており，膨大になりがちな操作 履歴の中から意味のある部分を見つけ出した結果である .

システムか関係のある情報だけを Tracking 空間に収 集し，設計に関する過程として意義ある情報を Capture 空間に抽出できる点に本研究の意義がある．
表 2 操作履歴記述のための語彙 (代表例を抜粋)

\begin{tabular}{|c|c|}
\hline \multicolumn{2}{|c|}{ 上位概念 下位概念 } \\
\hline ドキュメント & $\begin{array}{l}\text { 機能分解木ファイル (機能構造の媒体) } \\
\text { 方式ファイル (方式知識の媒体) }\end{array}$ \\
\hline \multicolumn{2}{|c|}{ ト ドキュメントレベル活動 } \\
\hline $\begin{array}{l}\text { ドキュメントを } \\
\text { 修正する }\end{array}$ & \begin{tabular}{|l} 
機能分解木ファイルを修正する \\
方式ファイルを修正する \\
\end{tabular} \\
\hline $\begin{array}{l}\text { ドキュメントを } \\
\text { 他者に提供する }\end{array}$ & \begin{tabular}{|l} 
機能分解木ファイルを他の設計者に提供する \\
方式ファイルを他の設計者に提供する
\end{tabular} \\
\hline $\begin{array}{l}\text { ドキュメントを } \\
\text { 取得する }\end{array}$ & \begin{tabular}{|l} 
機能分解木ファイルを取得する \\
方式ファイルを取得する
\end{tabular} \\
\hline $\begin{array}{l}\text { ドキュメントを } \\
\text { 関係づける }\end{array}$ & $\begin{array}{l}\text { 機能分解木ファイルと方式ファイルにリンクを } \\
\text { 作成する }\end{array}$ \\
\hline $\begin{array}{l}\text { ドキュメントを } \\
\text { 組織へ提出する }\end{array}$ & $\begin{array}{l}\text { 機能分解木ファイルを組織へ提出する } \\
\text { 方式ファイルを組織へ提出する }\end{array}$ \\
\hline $\begin{array}{l}\text { ドキュメントを } \\
\text { 組織が認定する }\end{array}$ & $\begin{array}{l}\text { 機能分解木ファイルを組織が認定する } \\
\text { 方式ファイルを組織か認定する }\end{array}$ \\
\hline
\end{tabular}

$4 \cdot 1$ キャプチャ機能における解釈ルール

Tracking 空間から Capture 空間への写像において, 写 像関係を構筑するためのルールを本研究では解釈ルール と呼ぶ . この解釈ルールの役割は，キャプチャすべき意 味のある情報だけに注目して Capture 空間で有効なモデ ルを構築することである . 構築されたモデルは , 例えば， 設計者の行為がどのような経緯からだったのかといった 設計過程に関する意図を明示化する .

解釈ルールの構成はプロダクションルールと同等のも のである.1 つのルールは条件と帰結から構成され，条 件が成立したときに帰結が導かれる．解釈ルールでは特 に，下位レベルの活動を条件として上位レベルの活動を 帰結する . 本研究では, システムで観測できるファイル 操作を下位レベルとして, 設計者個人による設計活動レ ベル, 設計者間の相互作用レベル, 設計活動全体のレベ ルを設けており，複数の解釈ルールを用いて段階的に推 論する。

弚の結果，具体的な Tracking 空間の構成要素と，抽 象的な Capture 空間の構成要素との間に写像関係が成 立する．例えば，機能分解木ファイルを送る」や「機能 


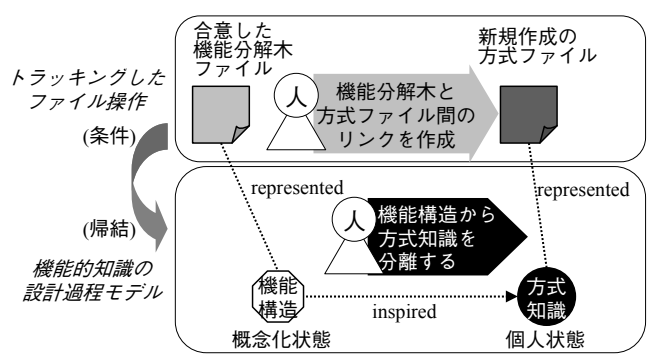

図 4 方式知識の体系化過程の解釈ルール (一例)

分解木ファイルを受けとる」といったシステムで捉えら れる具体的なファイル操作は, 最終的に Capture 空間に おいて，個人活動レベルで「設計案を伝える」と「設計 案の獲得」，設計者間の相互作用レベルで「設計案の伝 授」,設計活動全体のレベルでは「知識の共有」と写像さ れる.このように段階を経るごとに抽象度が上がる．ま た, Tracking 空間と Capture 空間との関係は, 一対一 の関係に限定されるものではなく，多対一になる場合も ある

解釈ルールの一例を図 4 に示す. 図 4 は設計文書間の リンク作成操作から機能構造と方式知識の関連性を解釈 するルールである . 図 4 上側がトラッキングした操作履 歴に対する条件を表す．この条件は表 2 に示した日常業 務行為に関する語彙て記述する . 図 4 下側は产の操作履 歴を解釈した結果を表し，表 1 に示した概念を用いて記 述する.この解釈結果は，ドキュメントに記述された機 能構造の状態と状態変化, 理由となる設計活動など, 操 作履歴では明示化されない暗黙的な内容を含む．この解 釈ルールを Tracking 空間に対して適用することにより， ルールの範囲内という制限はあるものの, システムは機 能的知識の修正・体系化過程を自動的に解釈できるよう になる。

3 章で説明したように設計に関わる過程には機能構造の 修正過程と方式知識の体系化過程が存在する .このため 適切な過程を解釈するルールには, 前者を解釈するルー ルと後者を解釈するルールの兰れ光れが存在する．

\section{$4 \cdot 2$ 機能的知識の修正・体系化過程のキャプチャ}

本システムはプロダクションシステムの基本構成を踏 襲しており，以下の手順を繰り返すことによって設計に 関する過程全体をキャプチャする．

(1) ユーザのファイル操作を取得し, Tracking 空間に 蓄積する。

(2) Tracking 空間の状態に応じて, 解釈ルールの集合 の中から適用可能なルールを選択する . 前述したよ うに Tracking 空間は表 2 の語彙に基づいて記述さ れ，解釈ルールの条件もまた表 2 の語彙に基づいて 記述されるので, システムは個々の解釈ルールの適 用可能性を調べることができる .

（3）選択した解釈ルールを適用して，下位レベルの活
動から上位レベルの活動へと解釈する．

（4）解釈結果をこれまでの過程につながる新たな過程 として Capture 空間に追加する .

以上の動作の結果 , 設計ドキュメントの操作履歴ではな く機能的知識のレベルでの過程に関する情報を Capture 空間に蓄積する。

本節では, 上記の動作について簡略化した具体例を通 して説明する.説明上の仮定として，設計者はホームベー カリーの要求仕樣のうち「パンをつくる」機能の概念設 計を行うとする .

$\S 1$ 設計案の修正過程のキャプチャ

SOFAST で「パンをつくる」などの機能を記述する場 合，例えば方式知識の記述されたファイル v1などを参考 に機能分解していく(図 5(a))「パンをつくる」機能につ いてある程度まで機能分解を完了させた後, ホームベー カリー設計グループの意見を聞きたい場合がある .レビュ ワーに機能分解木ファイル $\mathrm{v} 2$ を送り，受けとつた人は設 計案のレビューを開始する .この一連の操作がトラッキ ングされて解釈されることで, 図 2 の [1] の部分の機能 構造の修正過程モデルが構筑される．

設計者は機能分解木ファイル v2 を閲覧し，SOFAST で修正しながら機能分解を進める (図 5(b))。例えば，v1 に記述されたパンの材料を単純に混ぜる方法では生地に ならないため，v4に記述されたパン職人のように材料 を混ぜてかつ力を加える「ひねりのばし方式」を選択し， SOFAST を用いて修正したファイル v5を作成したとす る .このファイル操作か解釈されることで, 図 2 の [2] の 部分の機能構造の修正過程モデルが構築される.

このファイル v5 を元の設計者に伝えてミーティング を開く (図 $5(\mathrm{c}))$. ミーティングで合意に達成し，合意を 反映させた設計案を提出したとする . 合意設計案の提出 からデザインレビューが行われたと解釈され，図 2 の [3] の合意設計案にいたるまでの過程がモデル化されて蓄積 される.こうして誰がどの機能に対してどの方式知識を 選択したかといった過程の共有が可能となる．

$\S 2$ 方式知識の体系化過程のキャプチャ

次回の設計が円滑に進むようにするため, 設計案から 再利用性の高い知識を抽出して設計基盤を作ることは重 要である.本システムでは光の過程をキャプチャして方式 知識の形成された状況を後の設計で参照可能にする .こニ では「パンをつくる」設計案が完成してファイル v1 が提 出された場合を想定し, 兴のファイル $\mathrm{v} 1$ から SOFAST を用いて「ひねりのばし方式」を分離してファイル $\mathrm{v} 2$ に 記述したとする (図 6(a)).

分離された方式知識は元の機能分解木に依存する場合 があるため，SOFAST て編集して共有性・再利用性を高 めて洗練する．ここでは,「生地を混ぜる」ための「ひね りのばし方式」 $\mathrm{v} 2$ をより明確・一般化するために「力を 存在させる」機能へと分解し，产の機能を達成する「ねじ り荷重方式」v4 亿と修正する (図 6(b)) .この方式は, 対 


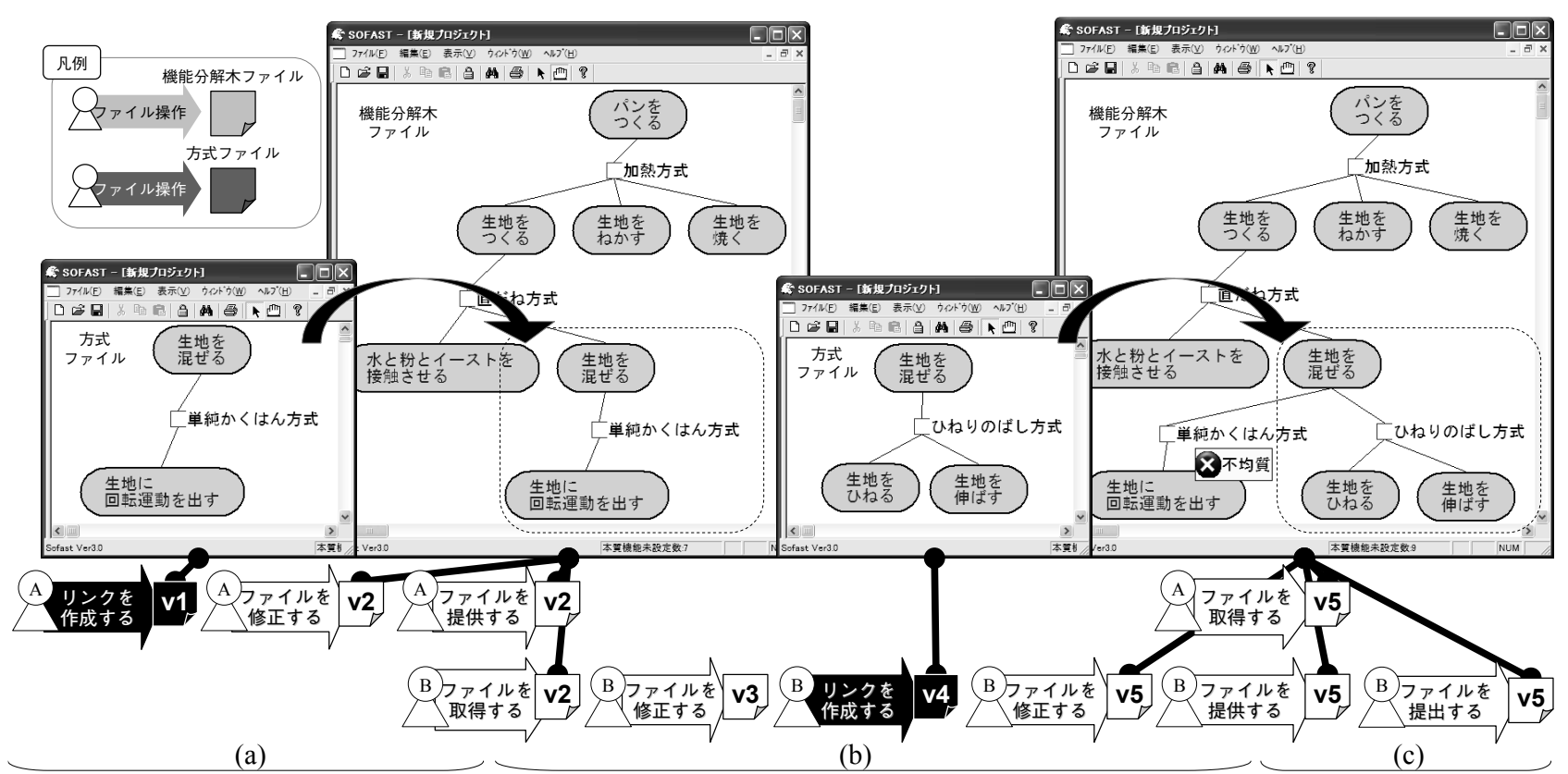

図 5 機能構造の修正過程のキャプチャ(Tracking 空間)

象物に対して回転軸方向に形状を歪ませると内部に力が 生じるという原理の元に「力を存在させる」機能を達成 し，修正前に比べて一般的で再利用性が高くなっている．

最終的に「ねじり荷重方式」が組織に認定されること て既存の体系へと組み入れられる (図 6(c)). 本研究では 既存の体系へ組み込む操作として，既存の方式ファイル 等とのリンク作成という特定のファイル操作を対応させ ている .これらか観測されたとき Tracking 空間に「ファ イルを認定する」という操作か記録される .

ここまで述べたようなSOFAST の操作履歴のトラッキ ングと光の解勫によって図 3 て説明した方式知識の体系 化過程がモデル化される (図 6 の (a) (d) カ泪 3 の [1] [4]に対応) . モデル化された過程では同樣の方式を用い た設計案を探索できる．以下に探索の例を示す．市販さ れている家庭用洗濯機の中には，傾斜面のついた回転盤 を底部に持つものがある (図 $6(\mathrm{~d}))$.この回転盤で洗濯物 全体をねじることにより個々の洗濯物に力を存在させて 污れを落とす．この方式は「ねじり荷重方式」と原理的 に同一であり，「パンをつくる」設計案 v1 から家庭用洗 濯機の設計案 $\mathrm{v} 5$ へ，過程を辿ることによる探索可能性 を示せたといえる。

方式知識は機能の達成方法を概念化したもので設計対 象・領域の独立性が高いため, 上記のような異なる要求 機能をもつ機能構造間であっても共通の方式知識を探索 したり，既存の装置の方式知識について他の装置で用い られていた方式知識で代替するといった再利用が可能で ある、本研究では, 設計案から方式知識を抽出する過程 や方式知識の利用された過程といった付加情報を明示化 することで，他の装置への転用手順の明確化や，方式の 体系化に関わったキーパーソンの探索などが新たに期待 でき，方式知識の再利用性の向上に貢献する .

\section{5. 本システムの実装と 評価}

本研究では，知識管理フレームワークを採用して ad hoc な実装ではなくナレッジマネジメントとして理論的 な裏付けのある方法で, 日常業務の知識管理をトータル に支援する枠組みを実装した . 本章ではまずフレームワー クの簡単な概要とキャプチャ機能の実装について説明し， 次に本システムへの評価を通して目的の達成を確認した ことを述べる．

\section{5·1 Kfarm フレームワークに基づいたシステム実装}

筆者らはこれまで組織における知的活動の支援システ ムを研究してきた [池田 01, Hayashi 03] . 乥の研究にお いては, 知識だけでなくスキル・能力も含めて一般化した 知を対象にして沉用的な組織活動プロセスをモデル化し， そのモデルに基づく組織知管理フレームワーク Kfarm を開発してきた .

Kfarm フレームワークは, 組織知のモデルを構筑・管 理するサーバK-granary を中心に , 2 種類のクライアン 卜一個人活動を支援する K-field と，知の管理を支援す る K-ranch house一で構成される .

K-field は知を活用する環境で, ユーザ自身の知や他者 の知に関する認識を助けるとともに, 活動をトラッキン グするセンサとして振る舞う .一方の K-ranch house は 知を管理する環境で, 組織の状態の把握, 意義のある知 の認定 , 共有・配布などを支援する . K-ranch house は 組織知に関するモニタ機能を提供する .

K-granary は Kfarm の核となるサーバである . ユー ザからの情報要求に受動的に応じるとともに, 組織知の 変化 (特定の知への関心の集中・体系知の更新など) を能 動的に把握して通知する. K-granary の目的はドキュメ 


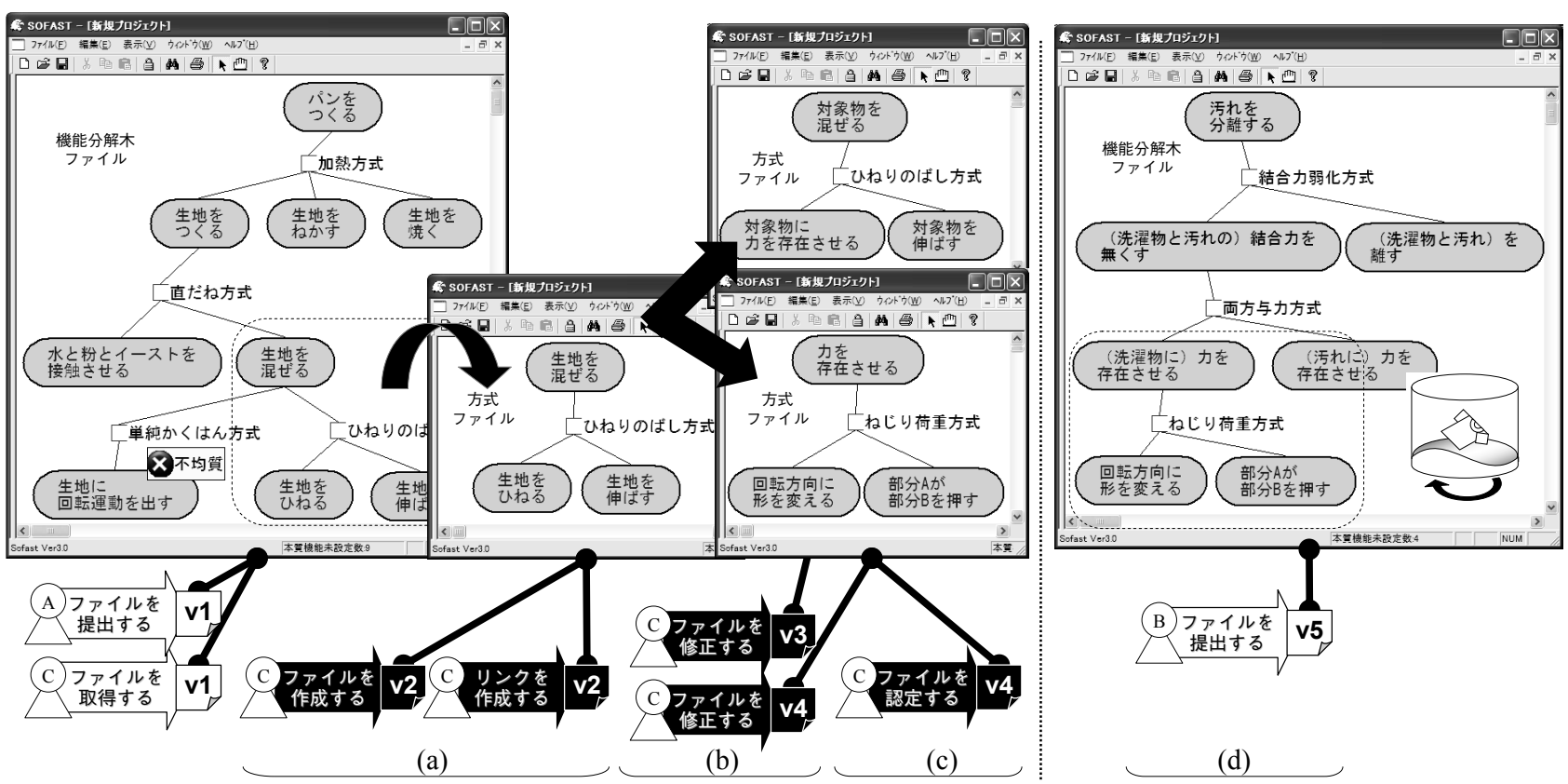

図 6 方式知識の体系化過程のキャプチャ(Tracking 空間)

ント内容の分類だけでなく, 人の多角的な活動と光の間 の連携を促す組織知のアウェアネス情報をクライアント に提供することである .この目的達成のためにこれまで 筆者らは,組織知をモデル化する機能を構築した .この機 能によって生成されるモデルを組織知モデルと呼ぶ . 組 織知モデルは, ユーザプロファイル, ドキュメントリポジ トリ，および系統グラフからなる . 系統グラフ [Hayashi 02]は組織知と組織活動の時系列情報であり，K-field / K-ranch house でトラッキングしたログに解釈ルールが 適用されて生成される.

本研究では上述した Kfarm をべースにして機能的知 識の修正・体系化過程のキャプチャ機能を実装し，従来の SOFAST のもつ機能分解木の記述支援と統合して, 設計 意図に関する統合的な知識管理支援システムを構築した 。 図 7 に設計者用の環境のスクリーンショットを示す.こ の環境は Kfarm におけるユーザ環境 K-field をべースに しており，モデル化された機能的知識の修正・体系化過 程に関する情報を提供するとともに，設計者によるファ イル操作をトラッキングする .

図 7(a)では保有する設計案に関する情報が提供され， 例えば， 3 章の図 2 における「設計案を伝授する」といっ た相互作用レベルの活動解釈結果に基づき，他の設計者 との情報交換の結果などが提供される . 図 7(b) では他の 設計者の保有する設計案の情報が提供され，例えば，体 系的に整理・蓄積されて体系化状態となった最終設計案 や方式知識などが提供される.また，図 2 の機能構造の 修正過程や图 3 の方式知識の体系化過程はグラフとして 図式化されて提供される (図 7(c)). 設計者は機能構造の 修正過程などを直接参照して, オリジナルの設計案を参 照するといったことが可能になる．

本システムでは, 設計案や方式知識がファイルとして
表示されており，設計者がファイルに対して操作しよう としたときには, システムは状況に応じたファイル操作 メニューを提示する．例えば，共感状態ではない設計案 か記述されたファイルでは，「他の設計者に配布する」と いったメニューが提示される．設計者は適切なメニュー 項目の選択という簡単な操作によって機能分解木ファイ ルなどを操作・管理する .このときのファイル操作が卜 ラッキングされて蓄積・集約され，4 章の図 5 や图 6 で 示したようなファイル操作履歴が形成される .これらの トラッキングされたファイル操作履歴が K-granary で集 約・解釈されることで， 3 章の图 2 や図 3 で示した設計 に関する過程へとモデル化される .

K-granary では, Apache Tomcat 上のサーブレット がK-field/K-ranch house と通信して操作・管理履歴を 収集し，SWI-Prolog で記述された解釈エンジンが光の ログを解釈する．4 章で説明した解釈ルールをこの解釈 エンジンが用いてモデルを構成する．構成されたモデル は図 7(c)のパネルを通じて設計者に提供される.設計者 は図 7(c)のノードを選択し,SOFAST を起動して機能 分解木の閲覧・編集をする.

\section{$5 \cdot 2$ システムの評価}

現在, 住友電気工業 (株) 生産技術部では SOFAST を 実務に活用している.本研究で構築したシステムについ てデモ・試用を通して技術者から実務上の観点で評価し て頂き，本研究の目標が達成できたことを確認した .

まず, 現状の SOFAST の操作に対して，機能の増加に 比べて手間の増加が無視できる程度であったために，技 術部の方から SOFAST の操作が簡単になったと感じる という意見を得た . 例えば，目的の機能分解木を探すと き，現状の SOFAST ではリスト状に並らシので探すのが 


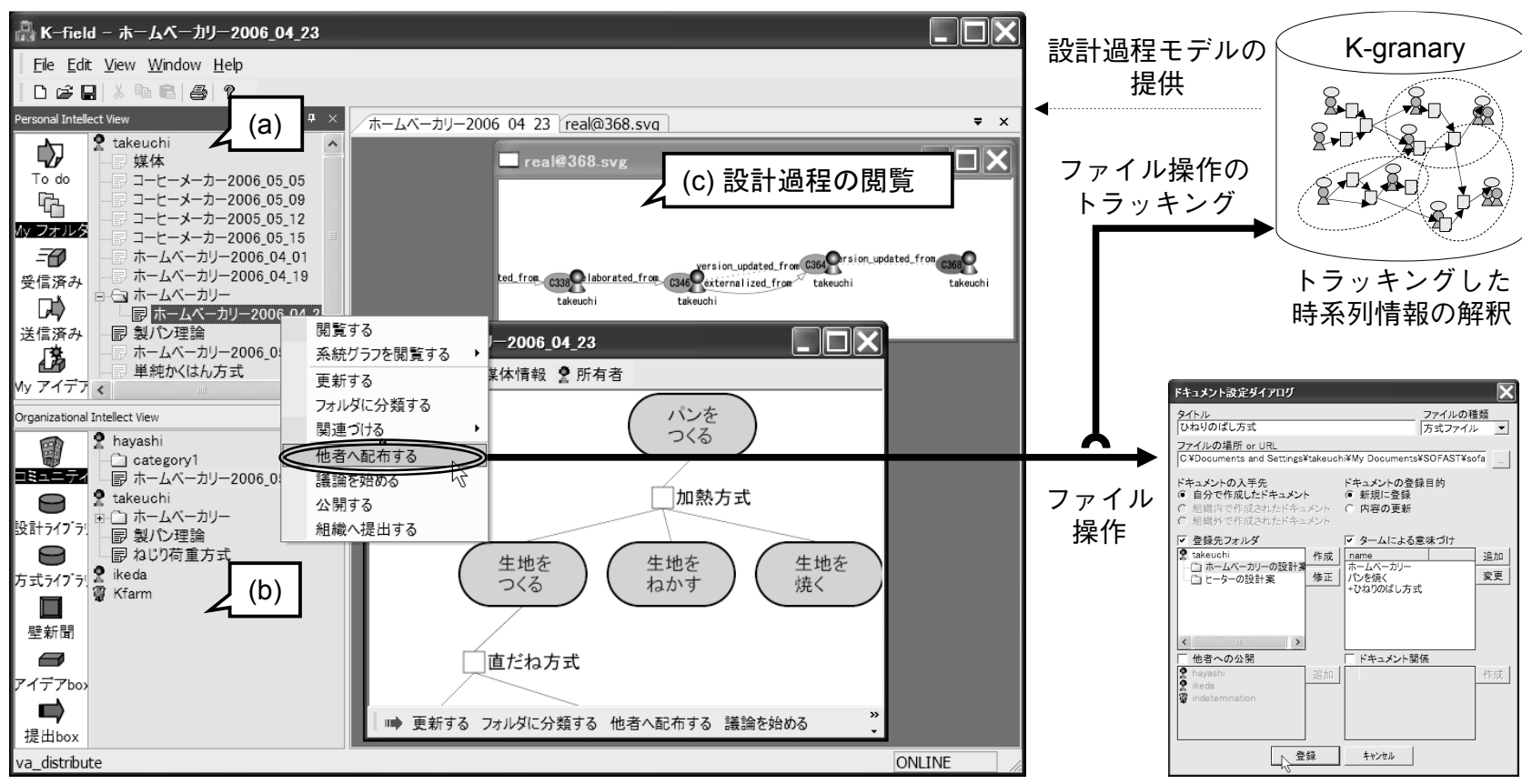

図 7 システムのスクリーンショット (K-field ベース)

大変であったが, 図 7(c) のように修正過程がグラフとし て表示されると適切な機能分解木を選びやすいといった 意見である . 本研究ではこのような機能構造の修正過程 を生成するために，設計者のファイル操作をトラッキン グしているにもかかわらず上記のような意見が得られた ことから，設計業務で忙しい設計者に新たな負担をかけ ないという操作上の目標を達したといえる .

このように手間か軽減される上に，実務において大き なメリットが得られる評価を得た 。

(状況 1) 不具合対策

現場では，SOFAST て記述された機能分解木に対して 類似の不具合が度々発生する.しかし，不具合を対策した 人の知識が他者に適切に伝わっておらず不具合対策が繰 り返されることがあった．本研究では設計案の修正過程 および修正に関わった人が明示的になるので，不具合対 策に関する有用な情報を明確に残すことが可能になった． （状況 2）改良設計

既存の装置の設計で , なぜそのような設計になったの かが分からず，修正してもいいかどうかの判断がつかな い場合があった . 修正すれば意図していない不具合が発 生する恐れがある . 本研究では過去の機能分解木の修正 過程および修正に関わった人が参照可能になるので，こ の種の不具合の発生を減らすことができる .

また，よりよい改良設計のために数多くの方式知識の 把握が求められている. 初心者は方式知識の学習時に適 切な教材を選択するため, 過去の設計案の関連性を知る 必要があった . 本システムによる方式知識の体系化過程 の参照によって，弚の学習支援が可能になる．

（状況 3) 技術の進歩への追従

技術の進歩に合わせて基本となる機能分解木を修正す る場合や派生の木を作成する場合，現状では両者の関連
がなくなり，誰が光の技術を考案したのかといった重要 な情報を辿れなくなっていた．本研究では機能分解木の 修正過程および方式知識の体系化過程の両方の過程の俯 瞰が可能になり派生関係などの把握が容易になる .

以上の状況は , 本システムが実務のどのような状況に おいて効果を発揮できるかについて，デモ・簡単な試用 の後に現場の技術者の経験を踏まえてあげてもらったも のである . 上記のような技術者からの評価により，本シ ステムが実務において効果の見込めることが確かめられ た . 本システムはまだプロトタイプであって実用化・実 務への定着には至っていないが, 実務において活用され た場合は上述の効果が見込まれる．

一方で, 本研究の実運用に向けた課題も明らかになっ た．本研究では方式知識の体系化過程において，管理者 による認定作業が重要だとした．しかし，確信をもって 認定することは管理者といえども難しいという指摘を得 た.認定には, 組織にとって意義のある内容の認定と，組 織内で十分に共有・明示化された状態の認定という 2 種 類の認定を含むと考えられる . 前者については今後の検 討事項だが, 後者の認定に関しては体系化過程のモデル の提示などにより支援可能だと考えている .

\section{$5 \cdot 3$ 改良設計の実例への適用}

本節では, 住友電工から頂いた実例が本研究で提案す る枠組みて記述可能であることを示す．

対象とする事例は, 薄肉チューブの穴検査装置の改良 設計である．薄肉チューブは穴があれば不良品となるの で，この装置ではチューブに穴がないことを検査する． チューブの内側から照明を当てて外側からカメラで撮像 することで，穴を「明るい点」として検出する．しかし， 


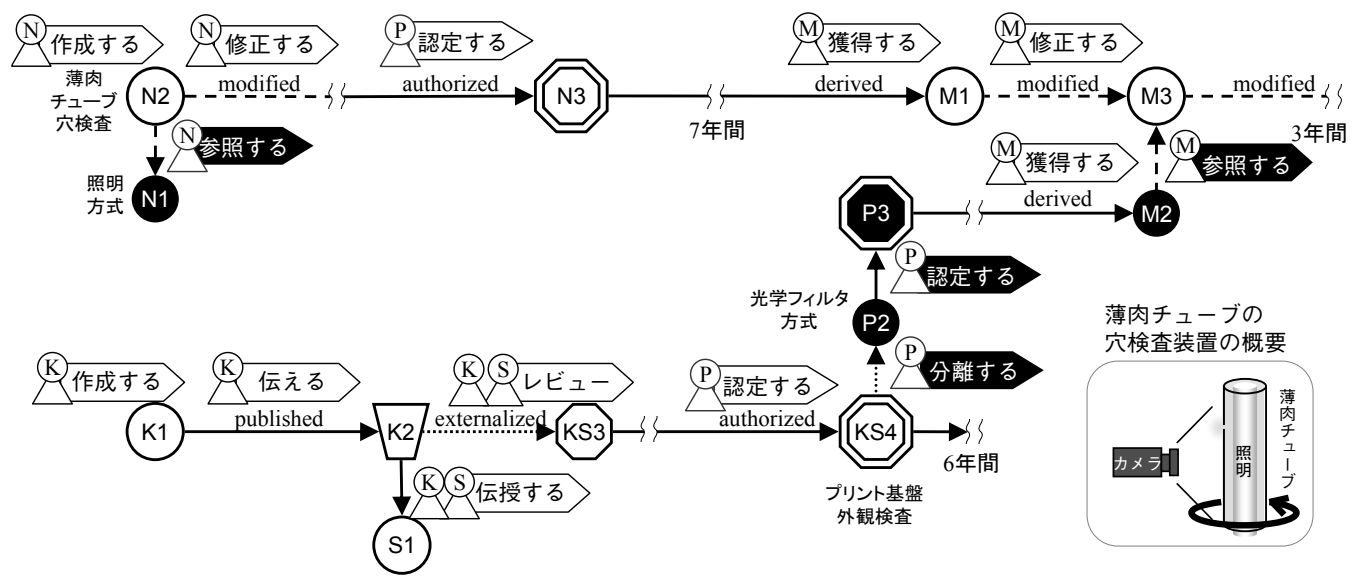

図 8 薄肉チューブの穴検査装置の改良設計過程の記述

この検査装置は肉厚が局部的に薄い場合に穴が開いてい ると過検出する問題点があった . 弚の対策として, 過去 の開発事例の中から照明の波長特性に着眼して, カラー フィルタをカメラの前に追加することで性能向上を図る 目処を付けた .

本事例をモデル化したものを図 8 に示す．この検査装 置は 10 年前に $\mathrm{N}$ 氏か設計・製作した (初期案 $\mathrm{N} 2$, 最終 設計案 N3). 7 年後, 当初の設計案で用いられた照明方式 N1 では発生した不具合に対応できず, 改良設計のニー ズが発生する. 光の対応を $\mathrm{M}$ 氏が 3 年前に光学フィル タ方式 M2 を用いて行った . 方式 M2 は体系化された方 式 P3 の獲得であり，体系化前の方式 P2 は設計案 KS4 で使われていた．つまり，M氏による改良設計の発想支 援となったのは 6 年前に $\mathrm{K}$ 氏によって開発された異なる 検査装置 (初期案 K1，最終設計案 KS4) である . その開 発過程においては S 氏がアドバイザとして参加しており， $\mathrm{K}$ 氏の検査装置の開発に影響を与えた .

従来の SOFAST ではこのような場合，資料として管 理されて残るのは対策後の最終的な機能分解木 M3 だけ であった . 機能分解木にも不具合事象の情報はメマーク として記述することはできたが下記の樣な問題があった .

（1）機能分解木の修正は他の設計案をべースにするこ とが多いが谷の関係が残らないため, 元の機能分解 木に比べて情報量がかなり減少する .

（2）修正・改良の経緯が不明確で，どの段階で新しい 機能か織り込まれたのかなどが分からない. $(\times$ マー クとして記述すると自然言語なので探し難い)

(3) 他の最終設計案の検索に手間がかかり，技術の広 がりを把握しにくい .

本システムを用いることで機能分解木の修正過程が明 確になり，どのタイミングでどの技術・アイデアを用い たかか明確となる．5.2 節の状況 3 で述べたように，技術 の進歩への追従で効果があるという意見を得たのは，こ の点を技術者の方に評価して頂いたからだと考えている また，本システムでは過去の機能分解木との差異を参照 できるので, 例えば, 設備のバージョンアップの経緯や
誰が弚れに関わつたなどの情報が明示化でき，光の意図 を知る手掛かりが得られるという利点もある .5 .2 節の 状況 2 で述べた改良設計での効果に関する意見は，この 利点を肯定するものだと考えている．

このように , 現場の技術者と共同してモデル化した本 システムの試用を通して，設計に関する過程に関して得 られる情報量を飛躍的にアップさせる能力があることを 確認した。

\section{6.お わりに}

設計根拠に関する研究は多岐にわたる．弚の中でも設 計過程に焦点を合わせている代表的な研究を紹介する.冨 山らは CAD 等のシステム操作履歴を集約し知識操作過 程を導出するシステムを提案している [野間口 05] .この システムは $\mathrm{KIEF}$ を $\mathrm{CAD} / \mathrm{CAE}$ 統合環境として用いて 操作履歴を人か理解可能な形で文章に記録するとともに， 設計者への質問を通して設計作業に関する暗黙的な知識 を引き出光うとする . また, IBIS[Kunz 70] を代表とす る issue ベースのシステムは, 問題解決過程を ISSUE(問 題，問い)・POSITION(立場，観点 $) \cdot A R G U M E N T($ 立 場を支持する意見) およびそれ光れの関係で表す．設計 過程において ISSUE は要求機能や不具合，一般的な質 問などが相当し，POSITION は設計案や方法，質問に 対する解答などが相当すると考えられる

本研究では設計意図に関わる過程として，機能分解木 に記述された過程 (機能発揮過程) と機能分解木谷のもの の過程 (設計案の修正・洗練過程, 方式知識の再利用性 · 汎用性を高める体系化過程) に着目した . 両者のうち後 者が設計過程を考えるうえでの参照情報として重要であ り，本研究では光の明示化のための記述枠組みとキャプ チャ機能を開発した .この機能はSOFAST に関連する 日常業務の履歴を取得・解釈することで，複雑な操作を 求めることなく機能的知識というレイヤでの修正・体系 化過程をキャプチャする.この機能の追加によって機能 発揮過程を扱う SOFAST を統合的機能的知識管理ツー 
ルへと発展させ，技術者へのデモ・試用を通して目的の 達成を確認した。

本システムの開発は, 汎用性の高い包括的な組織知管 理フレームワーク Kfarm をべースにした．Kfarm は単 体でも基本的な知識管理システムとして動作するが，内 部構造は一般的部分とドメイン固有部分の切り分けが明 確になっているので, 設計ドメインへの適用は 3 章・4 章で議論した設計過程に基づく解釈ルールを加えるだけ よく,SOFAST を自然な形で知識管理環境に埋め込むこ とができた . 本システムについて現場の技術者からの実 務上の評価を得たことで, Kfarmのドメイン特化を受け 入れる柔軟性と実用システムの基盤となる能力を同時に 確認できた .

今後の課題としては, 不具合に関する知識への対応が あげられる.設計では不具合と対処に関する知識が重要 であるにも関わらず, 本研究では光の反映が不十分であ り，どのような過程を経て不具合に対処したのかを明確 に表現できるようにしたい，現在，機能的知識と不具合 知識を扱う統合モデル [Koji 05] を提案しており，光れ に沿った形で本研究も不具合知識の対処過程を捉えるよ うに発展させたい．

知識管理技術は，知識がどの組織でも扱われることか ら非常に汎用性の高いものになりがちである . 知識を統 合的に捉える汎用性が特徵の 1 つではあるが，実際は逆 に，組織の所属するドメインに合わせた固有の概念およ び概念間の関係を十分に扱えなくなるという問題が生じ てしまっている .このことから今後は，ドメイン特有の 概念および概念間の関係を汎用システムで処理できるよ うに支援するドメイン特化支援機能が必要と考える。

\section{謝 辞}

本システムに関して有意義なコメントを頂いた住友電 気工業 (株) 生産技術部の柏瀬雅一部長, 篠木秀次主席 に感謝します。

\section{$\diamond$ 参 考 文 献 $\diamond$}

[Chandrasekaran 93] Chandrasekaran, B., Goel, A. K., and Iwasaki, Y.: Functional Representation as Design Rationale, Computer, Vol. 26, No. 1, pp. 48-56 (1993)

[Davenport 98] Davenport, T. and Prusaki, L.: Working Knowledge, Harvard Business School Press (1998), (梅本克 彦訳：ワーキングナレッジ「知」を生かす経営, 生産性出版, 2000.)

[Hayashi 02] Hayashi, Y., Tsumoto, H., Ikeda, M., and Mizoguchi, R.: An Intellectual Genealogy Graph Affording a Fine Prospect of Organizational Learning., in Cerri, S. A., Gouardères, G., and Paraguaçu, F. eds., Intelligent Tutoring Systems, Vol. 2363 of Lecture Notes in Computer Science, pp. 10-20, Springer (2002)

[Hayashi 03] Hayashi, Y., Tsumoto, H., Ikeda, M., and Mizoguchi, R.: Kfarm: An Ontology-aware Support Environment for Learning-Oriented Knowledge Management, 教育 システム情報学会英文論文誌, Vol. 1, No. 1, pp. 80-89 (2003)

[布瀬 03] 布瀬 雅義, 柏瀬 雅一, 篠木 秀次 : 生産技術の体系化
と生産・設備設計, 人工知能学会誌, Vol. 18(2), pp. 114-118 (2003)

[池田 01] 池田 満, 林 雄介, 津本 紘亨, 溝口 理一郎: デュアル ループモデルに基づく知識マネジメント支援, 人工知能学会研 究会資料, pp. 19-26 (2001)

[來村 02a] 來村 德信, 溝口 理一郎 : オントロジー工学に基づく機 能的知識体系化の枠組み, 人工知能学会誌, Vol. 17, No. 1, pp. 61-72 (2002)

[來村 $02 \mathrm{~b}$ ] 來村 德信, 他: 機能オントロジーに基づく機能的知識 の体系的記述と光の機能構造設計における利用, 人工知能学会 誌, Vol. 17, No. 1, pp. 73-84 (2002)

[Kitamura 04] Kitamura, Y., Kashiwase, M., Fuse, M., and Mizoguchi, R.: Deployment of an Ontological Framework of Functional Design Knowledge, Advanced Engineering Informatics, Vol. 18, No. 2, pp. 115-127 (2004)

[Klein 93] Klein, M.: Capturing Design Rationale in Concurrent Engineering Teams, Computer, Vol. 26, No. 1, pp. 39-47 (1993)

[Koji 05] Koji, Y., Kitamura, Y., and Mizoguchi, R.: Ontology-based Transformation from an Extended Functional Model to FMEA, in In Proc. of the 15th International Conference on Engineering Design (ICED '05), pp. 323-324 (2005)

[Kunz 70] Kunz, W. and Rittel, H.: Issues as elements of information systems Working Paper, Berkeley (1970)

[Lee 97] Lee, J.: Design Rationale Systems: Understanding the Issues, IEEE Expert: Intelligent Systems and Their Applications, Vol. 12, No. 3, pp. 78-85 (1997)

[間瀬 02] 間瀬 久雄, 絹川博之, 森井 洋, 中尾 政之, 畑村 洋太 郎: 思考過程の思考展開図表現に基づく機械設計支援システム, 人工知能学会論文誌, Vol. 17, No. 1, pp. 94-103 (2002)

[McCall 91] McCall, R.: PHI: A Conceptual Foundation for Design Hypermedia, Design Studies, Vol. 12, No. 1, pp. 3041 (1991)

[溝口 99] 溝口 理一郎, 池田 満, 來村 德信: オントロジー工学基 礎論, 人工知能学会誌, Vol. 14, No. 6, pp. 1019-1032 (1999)

[溝口 02] 溝口 理一郎, 來村 德信, 布瀬 雅義 : オントロジー工学 の成功事例〜機能オントロジーに基づく生産技術知識の共有 . 再利用 , 人工知能学会研究会資料 (2002)

[野間口 05] 野間口 大, 下村 芳樹, 冨山 哲男 : 設計者の思考過程 のモデルを利用した設計知識管理システム, 人工知能学会論文 誌, Vol. 20, No. 1, pp. 11-24 (2005)

[野中 96] 野中 郁次郎, 竹内 弘高 : 知識創造企業, 東洋経済新報 社 (1996)

[OWL] OWL: http://www.w3.org/2004/OWL/

[Pahl 88] Pahl, G. and Beitz, W. eds.: Engineering Design a Systematic Approach, The Design Council (1988)

[Regli 00] Regli, W. C., Hu, X., Atwood, M., and Sun, W.: A Survey of Design Rationale Systems: Approaches, Representation, Capture and Retrieval., Eng. Comput. (Lond.), Vol. 16, No. 3-4, pp. 209-235 (2000)

[武田 94] 武田 英明, 冨山 哲男, 吉川 弘之 : 実験的手法に基づく 設計知識と炎の利用に関する分析, 精密工学会誌, Vol. 60 , No. 3, pp. 422-426 (1994)

[富山 90] 冨山 哲男, 吉川弘之 : 機能論構築を目指して - 設計 の立場から - , 精密工学会誌, Vol. 56(6), pp. 964-968 (1990)

[XTM 01] XML Topic Maps (XTM) 1.0 Specification (2001)

〔担当委員 : 中小路 久美代〕

2006 年 9 月 13 日 受理 


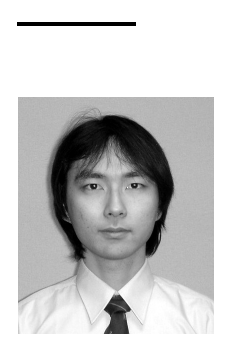

\section{紹 介}

\section{武内 雅宇 (学生会員)}

2002 年大阪大学基礎工学部システム科学科卒業 . 2004 年同大学院基礎工学研究科システム人間系専攻博士前期課 程修了. 現在, 同大学院工学研究科電気電子情報工学専攻 博士後期課程に在学中 .ナレッジマネジメント支援システ ムや学習支援システムに興味を持つ。

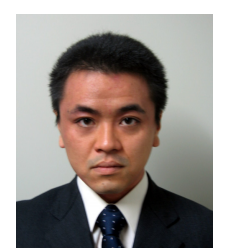

\section{小路 悠介(学生会員)}

2002 年大阪大学工学部電子情報エネルギー工学科卒業, 2004 年同大学院工学研究科電子工学専攻博士前期課程修 了. 現在, 同大学院工学研究科電気電子情報工学専攻博士 後期課程に在学中.機能を中心とした人工物に関するオン トロジー工学的考察と光れに基づく設計知識の共有に興味 を持つ。

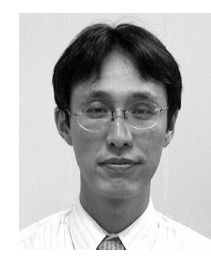

來村 徳信(正会員)

1991 年大阪大学基礎工学部情報工学科卒業. 1993 年同 大学院基礎工学研究科前期課程修了. 同年, 同大学産業科 学研究所技官. 1994 年同助手. 2003 年同助教授、現在 に至る、博士 (工学) .物理的システムに関するオントロ ジー工学的考察と, 弚れに基づいたモデル化と推論に関す る研究に従事. 1996 年人工知能学会創立 10 周年記念論 文賞受賞 . 情報処理学会会員 .

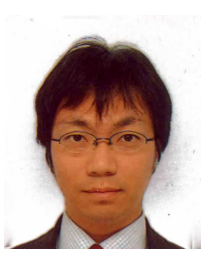

\section{林雄介(正会員)}

1998 年大阪大学基礎工学部システム工学科卒業 . 2000 年 同大学院基礎工学研究科システム人間系専攻博士前期課程 修了. 2003 年同大学院基礎工学研究科システム人間系専 攻博士後期課程修了. 同年, 北陸先端科学技術大学院大学 知識科学研究科助手, 2005 年大阪大学産業科学研究所特 任助手 (常勤), 現在に至る。博士 (工学) .オントロジー 工学, 知的教育システム, 組織知の創造・継承支援システ ムに関する研究に従事、情報処理学会, 人工知能学会, 教 育工学会, 教育システム情報学会, Intl. AI in Education (IAIED) Soc. The Asia-Pacific Society for Computer in Education (APSCE) 各 会員.

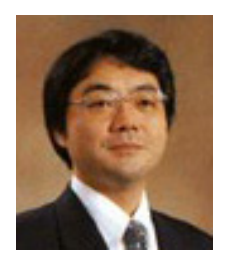

\section{池田＼cjkstart満(正会員)}

1984 年宇都宮大学工学部卒. 1986 年同大学院工学研究 科修士課程修了. 1989 年大阪大学大学院工学研究科博士 課程修了.同年宇都宮大学助手. 1991 年大阪大学産業科 学研究所助手. 1997 年同助教授. 2003 年北陸先端科学 技術大学院大学教授. 工学博士. 形式言語の構文解析, 仮 説推論, 帰納推論, 知的教育システム, オントロジー工学 の研究に従事 . 人工知能学会設立 10 周年記念優秀論文賞 受賞. 人工知能学会, 電子情報通信学会, 情報処理学会 教育システム情報学会, 教育工学会各会員、現在, 教育システム情報学会, 教育 工学会理事, 人工知能学会評議員, ISO/IEC JTC1 SC 36 WG2 (協調学習 に関する標準化) 主査。

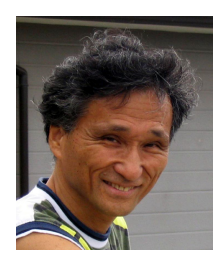

溝口 理一郎(正会員)

1972 年大阪大学基礎工学部電気工学科卒業. 1977 年同 大学院基礎工学研究科博士課程修了. 同年, 大阪電気通信 大学工学部講師, 1978 年大阪大学産業科学研究所助手 1987 年同研究所助教授, 1990 年同教授.現在に至る.工 学博士.パターン認識関数の学習, クラスタ解析, 音声の 認識・理解, エキスパートシステム, 知的学習支援システ ム, オントロジー工学の研究に従事. 1985 年 Pattern Recognition Society 論文賞, 1988 年電子情報通信学 会論文賞, 1996 年人工知能学会創立 10 周年記念論文賞, 1999 年 ICCE99 Best paper Award , 2005 年大川出版賞 (オントロジー工学) , 2006 年人 工知能学会論文賞, ICCE2006Best Paper Award 受賞. 人工知能学会理事, 同編集委員会委員長, 教育システム情報学会理事, 同編集委員長, Intl. AI in Education(IAIED) Soc. President,APC of AACE President を歴任. 現在, 人工知能学会会長, Semantic Web Science Assoc. Vice-President, 電子情報通信学会, 情報処理学会, 日本認知科学会, AAAI, IEEE 各会員. 